OF

BACTERIOLOGICAL NOMENCLATURE AND

TAXONOM Y

Volume 3

March 15, 1953

Number 1

NEWS AND NOTICES

DATES OF ISSUE OF BULLETIN IN 1953. The Board of Editors of the BULLETIN will be concerned during the next several months with the preparation of pertinent material for consideration by the Judicial Commission and by the International Committee on Bacteriological Nomenclature before the meetings to be held in Rome immediately preceding and during the 6th International Congress for Microbiology in September 1953. The proposals for amendments to the International Bacteriological Code of Nomenclature should be published and discussed, preliminary statements relative to Opinions should be presented, all Opinions of the Judicial Commission should be summarized and all special requests formulated. These agenda should be available not only to members of the Judicial Commission and of the Committee but to all microbiologists, particularly those concerned with bringing some order out of nomenclatural confusion.

To facilitate the realization of these objectives the Editorial Board has decided to change the publication dates for the four issues of the BULLETIN for 1953. The issues will appear as follows.

Number 1. March 15, 1953. To be somewhat decreased in size. To contain preliminary notices relative to the Rome Congress.

Numbers 2 and 3 . June 1, 1953. These two issues to be combined and expanded to constitute a Synopsis which will include:

a. Pertinent information relative to times and places of meetings of the Judicial Commission, of the International Committee, and of all Subcommittees 
and Committees concerned with Taxonomy.

b. All material, including Preliminary Statements, relating to Opinions requested from the Judicial Commission, with Summary of status of Opinions issued and pending.

c. All proposals for amendments to the International Bacteriological Code of Nomenclature.

d. Proposals relative to cooperation through the International Association of Microbiologists with the International Union of Biological Sciences and the United Nations Educational, Scientific and Cultural Organization (UNESCO).

e. The Agenda of the Judicial Commission.

f. The Agenda of the International Committee on Bacteriological Nomenclature.

g. The Agenda of the several Committees and Subcommittees.

Number 4. November 15, 1953. Summary of Committee and Congress actions relative to nomenclature and taxonomy.

\section{BOTANICAL COMMITTEE ON BACTERIA}

The Stockholm Botanical Congress authorized the establishment of an International Society for Plant Taxonomy to work in close association with the International Union of Biological Sciences. This society absorbed the Bureau of Nomenclature of the Congress. The General Committee of Botanical Nomenclature has as its secretary Prof. J. Lanjouw of Utrecht, who is also Chief Editor of Taxon, and as rapporteur of the Advisory Board of Nomenclature is ex officio a member of all committees. This General Committee of Botanical Nomenclature includes in its membership the secretaries of all committees.

At the Stockholm meeting Prof. O. N. Allen, Madison, Wisconsin, U.S.A. was chosen as secretary of the Committee for Bacteria. He is therefore also a member of the General Committee for Botanical Nomenclature. 